\title{
Palaeoclimate significance of speleothems in crystalline rocks: a test case from the Late Glacial and early Holocene (Vinschgau, northern Italy)
}

\author{
Gabriella Koltai $^{1}$, Hai Cheng ${ }^{2}$, and Christoph Spötl ${ }^{1}$ \\ ${ }^{1}$ Institute of Geology, University of Innsbruck, Innrain 52, 6020 Innsbruck, Austria \\ ${ }^{2}$ Xi' an Jiaotong University, Institute of Global Environmental Change, 28 Xianning West Road, \\ Xi'an 710049, Shaanxi, China
}

Correspondence: Gabriella Koltai (gabriella.koltai@uibk.ac.at)

Received: 10 August 2017 - Discussion started: 30 August 2017

Revised: 10 January 2018 - Accepted: 6 February 2018 - Published: 16 March 2018

\begin{abstract}
Partly coeval flowstones formed in fractured gneiss and schist were studied to test the palaeoclimate significance of this new type of speleothem archive on a decadal-to-millennial timescale. The samples encompass a few hundred to a few thousand years of the Late Glacial and the early Holocene. The speleothem fabric is primarily comprised of columnar fascicular optic calcite and acicular aragonite, both indicative of elevated $\mathrm{Mg} / \mathrm{Ca}$ ratios in the groundwater. Stable isotopes suggest that aragonite is more prone to disequilibrium isotope fractionation driven by evaporation and prior calcite/aragonite precipitation than calcite. Changes in mineralogy are therefore attributed to these two internal fracture processes rather than to palaeoclimate. Flowstones formed in the same fracture show similar $\delta^{18} \mathrm{O}$ changes on centennial scales, which broadly correspond to regional lacustrine $\delta^{18} \mathrm{O}$ records, suggesting that such speleothems may provide an opportunity to investigate past climate conditions in non-karstic areas. The shortness of overlapping periods in flowstone growth and the complexity of in-aquifer processes, however, render the establishment of a robust stacked $\delta^{18} \mathrm{O}$ record challenging.
\end{abstract}

\section{Introduction}

Speleothems from karst caves have contributed important information on past climate change from orbital to seasonal timescales worldwide (e.g. Johnson et al., 2006; Boch et al., 2011; Fohlmeister et al., 2012; Wang et al., 2014; Webb et al., 2014; Luetscher et al., 2015; Cheng et al., 2016). While the importance of these speleothems as palaeoclimate archives is firmly established, very little is known about the palaeoclimate potential of such deposits from non-carbonate settings. Since only $\sim 20 \%$ of the ice-free continental area of the Earth consists of carbonate rocks prone to karstification (Ford and Williams, 2007) speleothems from non-karstic settings may provide relevant palaeoclimate archives for semiarid (Koltai et al., 2017), super-humid (Schmipf et al., 2011) and subglacial environments (Frisia et al., 2017).

In comparison to other palaeoclimate archives, a key advantage of speleothems is that they can be dated with high precision by U-Th techniques up to about half a million years (e.g. Richards and Dorale, 2003; Scholz and Hoffmann, 2008; Cheng et al., 2013). Since silicate rocks usually contain much more uranium than limestones or dolostones (Wedepohl, 1995), the ${ }^{238} \mathrm{U}$ content of speleothems forming in cavities and fractures of crystalline rocks is commonly orders of magnitude higher, and therefore they require very small sample amounts to yield high-resolution chronologies (Spötl et al., 2002; Koltai et al., 2017).

The most widely used proxies of karst speleothems include stable oxygen and carbon isotopes, trace elements, growth rate and fabric changes (e.g. Frisia et al., 2003; McDermott, 2004; McMillan et al., 2005; Wassenburg et al., 2012). Although the majority of speleothem-based climate reconstructions utilized calcite speleothems, several studies indicate that aragonite can also record past climate, in particular rainfall variability (e.g. Polyak and Asmerom, 2001; Ridley et al., 2015; Wassenburg et al., 2016). 


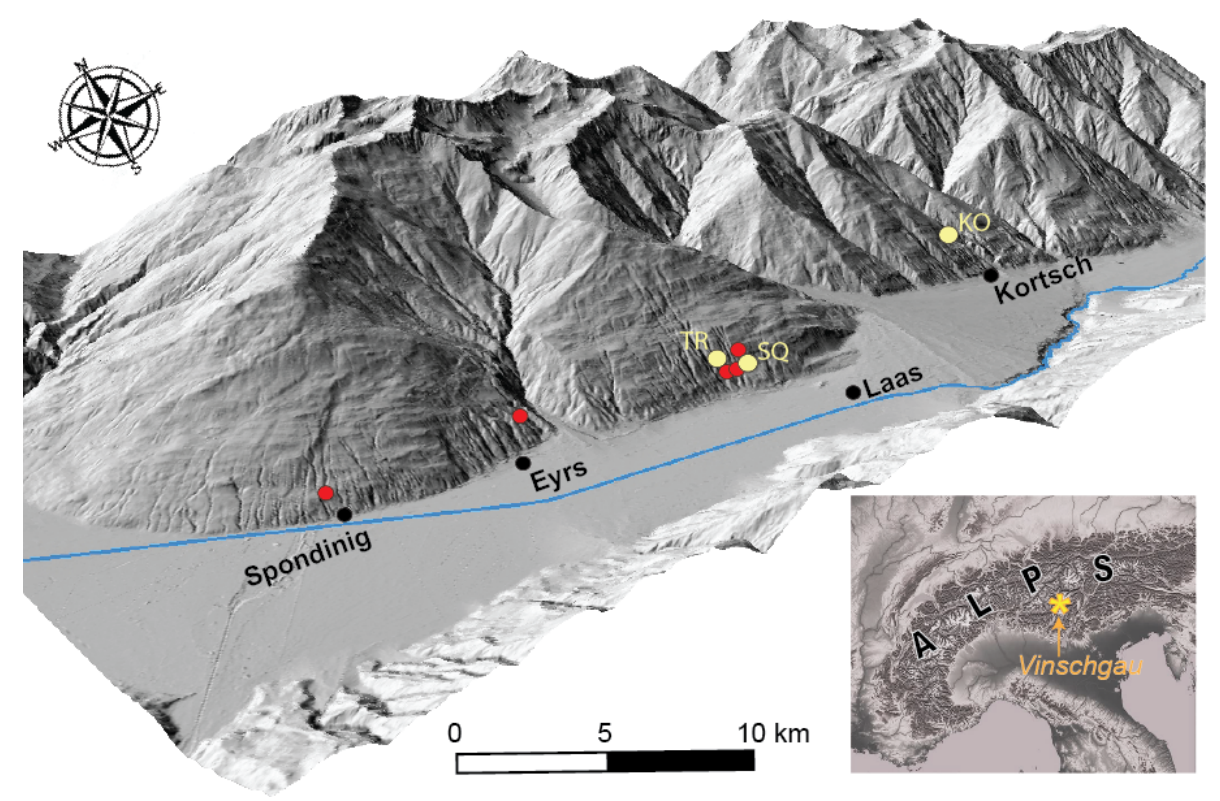

Figure 1. Oblique view of the Vinschgau valley. Red points show the occurrence of vein-filling flowstones in the lower part of the southfacing slope (Sonnenberg). Yellow points mark the three sampling sites.

Here, we present a well-dated, multi-proxy record of eight fast-growing flowstones from a non-karstic setting in a dry inner-alpine setting (Vinschgau). Unlike speleothems formed in karst caves, these calcite and aragonite flowstones were deposited in near-surface fractures created by gravitational mass movements. The aim of this study was to test the reliability of climate proxies preserved in this hitherto largely neglected type of speleothem archive. To this end we chose the Late Glacial to early Holocene time interval which is among the best characterized periods in the late Quaternary of the Alps based on studies of lake sediments (e.g. von Grafenstein et al., 1999, 2013; Magny et al., 2001; Ilyashuk et al., 2009; Lauterbach et al., 2011; Heiri et al., 2014), palaeoglaciers (e.g. Kerschner et al., 2000; Ivy-Ochs et al., 2008; Kerschner and Ivy-Ochs, 2008) and speleothems (Wurth et al., 2004; Luetscher et al., 2016). By comparing our speleothem data to these published records we explore the extent to which these non-karstic speleothems register the well-documented succession of rapid climate change during this time period.

\section{Site description and samples}

\subsection{Study site}

The Vinschgau is a E-W trending inner-alpine valley shielded by high mountain chains in the north, west and south. Although it is one of the driest valleys of the eastern Alps today (Fliri, 1975; ZAMG, 2015), local climate archives such as large debris-flow fans (which are largely inactive today) point to periods of distinctly more humid climate during the Late Glacial and Holocene in this valley.
The study area is comprised of paragneiss, orthogneiss and schists that are heavily fractured as a result of deep-seated gravitational mass movements along the Sonnenberg (Ostermann et al., 2016). These fractures provide pathways for groundwater flow. Due to pronounced water-rock interaction dominated by pyrite oxidation and the presence of large internal mineral surfaces created by the mass movements, these waters are highly mineralized. Their electric conductivity varies between 730 and $2300 \mu \mathrm{S} \mathrm{cm}^{-1}$ and they are characterized by elevated molar $\mathrm{Mg} / \mathrm{Ca}$ ratios between 0.3 and 3.3. Due to evaporation and concomitant $\mathrm{CO}_{2}$ degassing groundwater reaches supersaturation on the south-facing Sonnenberg slope, where springs are supersaturated with respect to calcite and (except for one spring) aragonite. Speleothems form as calcite and aragonite flowstones in the shallow subsurface and calcitic freshwater tufa deposits are present on the surface (Spötl et al., 2002; Koltai et al., 2017).

\subsection{Speleothem samples}

Eight vein-filling flowstones (Fig. S1 in the Supplement) were obtained from three different fractures (Fig. 1). It must be emphasized that the samples were found in the debris next to the fractures and their exact position within the fractures is unknown. LAS 1, LAS 2 and LAS 21 were collected at Törgltal (TR; $46.631^{\circ} \mathrm{N}, 10.680^{\circ} \mathrm{E}$ ), while LAS 6 , LAS 34 and LAS 72 are from Stollenquelle (SQ; $46.630^{\circ} \mathrm{N}$, $10.683^{\circ} \mathrm{E}$ ). These two sites are less than $1 \mathrm{~km}$ apart. The third site, Kortsch $\left(\mathrm{KO} ; 46.635^{\circ} \mathrm{N}, 10.763^{\circ} \mathrm{E}\right)$, is situated approximately $6 \mathrm{~km}$ east of SQ. Two samples (LAS 10 and 19) were collected there. 
Aragonite is present near the top of samples LAS 2, LAS 6 and LAS 21. Thus, the uppermost 12,15 and $6 \mathrm{~mm}$ of LAS 2, LAS 6 and LAS 21 respectively were not included in this study. As LAS 10 grew between $9.26 \pm 0.10$ and $10.22 \pm 0.06 \mathrm{ka}$ according to the depth-age model, the present study focuses only on the lower $21.4 \mathrm{~mm}$ of this flowstone (Fig. S1).

\section{Methods}

\subsection{Petrography}

Thin sections were analysed under transmitted-light and blue-light epifluorescence microscopy in order to identify characteristic fabrics and areas of replacement of aragonite by calcite. Furthermore, small aliquots of carbonate powder were obtained from LAS 2, LAS 6 and LAS 34 using a handheld dental drill in order to determine the mineralogical composition by X-ray diffractometry (XRD).

\subsection{Stable isotopes}

Samples for stable oxygen and carbon isotope analyses were micromilled at different resolutions. LAS 2 was sampled at $0.1 \mathrm{~mm}$ intervals, LAS1, LAS 6, LAS 34 and LAS 72 were micromilled at $0.15 \mathrm{~mm}$ increments. In order to reach multiannual resolution ( 3 years) LAS 6 was also analysed by using three $2.5 \mathrm{~mm}$ long parallel tracks milled with a $0.8 \mathrm{~mm}$ offset perpendicular to the lamination. LAS 10 and LAS 19 were analysed at $0.2 \mathrm{~mm}$, while LAS 21 was analysed at $0.25 \mathrm{~mm}$ resolution. Stable isotope measurements were performed us-

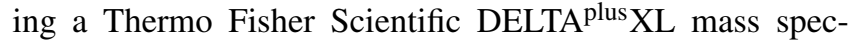
trometer. Isotope values are reported against the VPDB scale and the long-term analytical precision $(1 \sigma)$ of the $\delta^{18} \mathrm{O}$ and $\delta^{13} \mathrm{C}$ measurements is 0.08 and $0.06 \%$ respectively (Spötl, 2011).

\subsection{U-Th dating}

A total of 77 powder samples were prepared for radiometric dating. If present, primary aragonite was preferred over calcite, since aragonite-to-calcite transformation may alter the geochemical composition (e.g. Lachniet et al., 2012; Domínguez-Villar et al., 2017). U-Th dates were divided amongst samples as follows: 11 dates measured from LAS 2 and LAS 6, 10 from LAS 1, 8 from LAS 10 and LAS 21, 14 from LAS 19, 9 from LAS 72 and 6 from LAS 34. Aliquots were obtained for U-Th dating from distinct growth layers using a handheld drill. The weight of individual subsamples ranged between 1.0 and $9.0 \mathrm{mg}$.

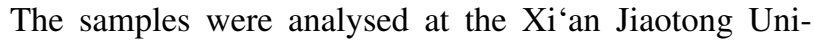
versity (China) following standard chemistry procedures of Edwards et al. (1987) to separate uranium and thorium. $\mathrm{U}$ and $\mathrm{Th}$ isotopes were analysed individually by using a multicollector inductively coupled plasma mass spectrom- eter (Thermo Fisher Neptune Plus) as described by Shen et al. (2012) and Cheng et al. (2013). Final ${ }^{230}$ Th ages are given with their $2 \sigma$ uncertainties as years before AD 1950 (BP). Corrected and uncorrected results are given in Table $\mathrm{S} 1$ in the Supplement. Corrected ages assume an initial ${ }^{230} \mathrm{Th} /{ }^{232} \mathrm{Th}$ ratio of $4.4 \pm 2.2 \times 10^{-6}$ of bulk Earth (Wedepohl, 1995). Separate age models for all samples were built using the StalAge algorithm (Scholz and Hoffman, 2011).

\section{Results}

\subsection{Petrography}

The crystal fabric of LAS 6, LAS 10 and LAS 19 is dominated by columnar fascicular optic calcite (Cfo; Frisia, 2015), showing undulose extinction due to the systematic change in the orientation of the $c$ axes (Kendall, 1985; Richter et al., 2011; Frisia, 2015). Detritus-rich layers are locally present in LAS 10 and LAS 19. Their average thickness varies from 25 to $50 \mu \mathrm{m}$ in LAS 10 and from 50 to $75 \mu \mathrm{m}$ in LAS 19 , but in the latter sample, detritus-rich layers up to $0.25 \mathrm{~mm}$ thick are also present.

LAS 72 is comprised of white acicular aragonite, while translucent calcite (Cfo) is also present in LAS 1, 2, 21 and 34 (Fig. 2a). XRD results indicate $100 \%$ calcite in the calcite layers of LAS 2 and 34. In LAS 2 and also in LAS 21 pristine aragonite islands are locally present in the calcite fabric that show no sign of dissolution, suggesting co-precipitation of aragonite and calcite (Fig. 2b).

Thin-section analyses of LAS 34 revealed the presence of mosaic calcite (Fig. 2c), a fabric indicative of recrystallization (e.g. Frisia, 2015). As recrystallization may have modified the geochemical composition of the calcite, only the aragonite fabric is discussed further in this study. None of the other samples show any sign of diagenetic alteration.

From 60 until $110 \mathrm{~mm}$ distance from top (dft), LAS 6 exhibits annual calcite lamina couplets which can be observed macroscopically as successive white and translucent laminae. The white laminae are rich in opaque particles, whose organic origin is confirmed by their strong epifluorescence (Koltai et al., 2017). Similarly, the inclusion-rich layers in the fascicular optic calcite of LAS 10 and LAS 19 show excitation under epifluorescence. Furthermore, weakly fluorescent laminae are present in LAS 72, while both calcite and aragonite layers in LAS 2 and LAS 21 appear dull.

\subsection{Stable isotope composition}

The summarized results of the stable isotope analyses are presented in Table 1. High-resolution stable isotope profiles of the flowstones collected near TR show very similar values for $\delta^{18} \mathrm{O}$, while carbon isotope values are more diverse. Even though $\delta^{13} \mathrm{C}$ minima are identical within the $1 \sigma$ analytical error in these samples, the highest carbon isotope values range from 2.4 to $7.3 \%$ (Table 1 ). 

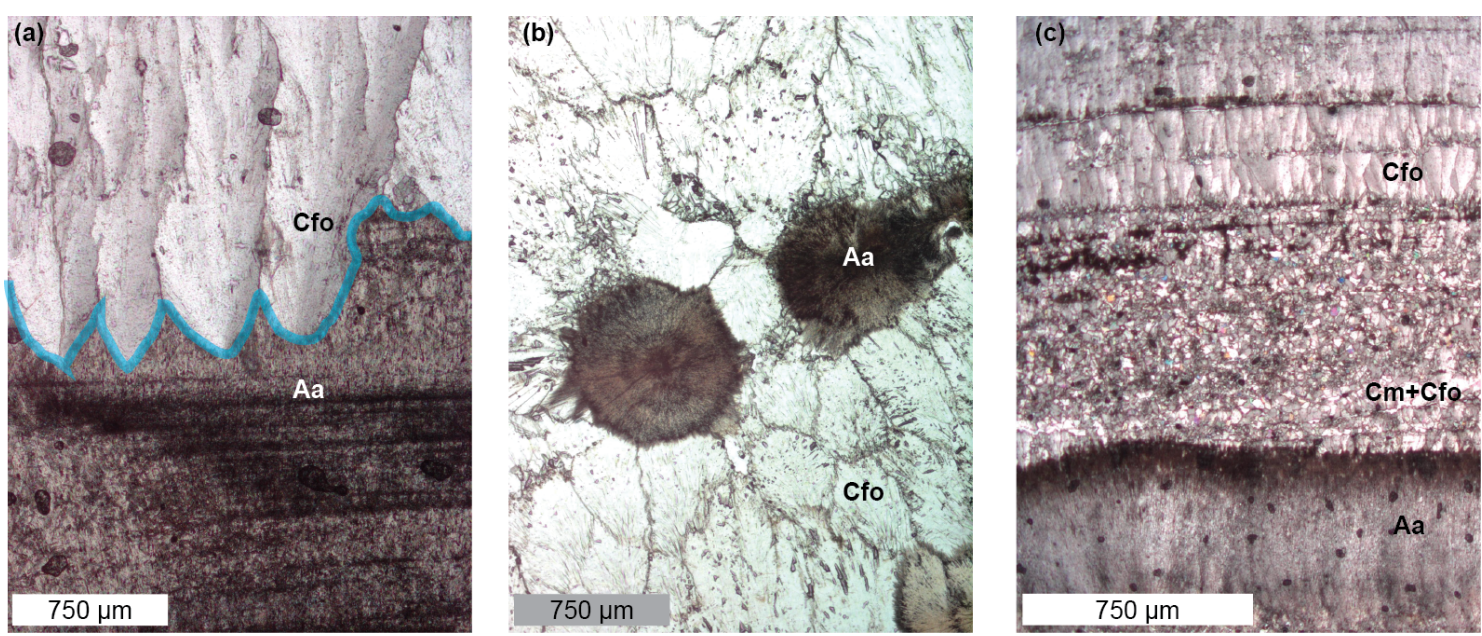

Figure 2. Aragonite and calcite textures. (a) Boundary of fascicular optic calcite (Cfo) and acicular aragonite (Aa), showing competing crystal growth between the two polymorphs (blue line, sample LAS 2). (b) Co-precipitation of primary calcite and aragonite (sample LAS 21). (c) Complex fabric dominated by mosaic calcite $(\mathrm{Cm})$ where fascicular optic calcite polycrystals (Cfo) are locally present between acicular aragonite (Aa) and fascicular optic calcite (Cfo, sample LAS 34).

Table 1. Stable isotope composition of the Vinschgau flowstones.

\begin{tabular}{llrrr|rrr}
\hline & & \multicolumn{3}{c|}{$\delta^{18} \mathrm{O}(\%)$} & \multicolumn{3}{c}{$\delta^{13} \mathrm{C}(\% \circ)$} \\
\cline { 3 - 7 } Sample & Mineralogy & Min. & Max. & Mean & Min. & Max. & Mean \\
\hline TR & & & & & & & \\
\hline LAS 1 & calcite-aragonite & -12.8 & -11.1 & -11.9 & -2.2 & 4.3 & -0.2 \\
LAS 2 & calcite-aragonite & -13.0 & -9.7 & -11.7 & -2.3 & 7.3 & 0.9 \\
LAS 21 & calcite-aragonite & -13.1 & -9.8 & -12.1 & -2.3 & 2.4 & -0.7 \\
\hline SQ & & & & & & & \\
\hline LAS 6 & calcite & -14.1 & -11.8 & -13.2 & -2.9 & -0.3 & -2.1 \\
LAS 34 & aragonite & -12.8 & -9.9 & -11.3 & -1.0 & 6.2 & 2.2 \\
LAS 72 & aragonite & -11.8 & -9.2 & -10.7 & -1.8 & 7.3 & 1.6 \\
\hline KO & & & & & & & \\
\hline LAS 10 & calcite & -12.3 & -10.3 & -11.3 & -5.6 & -1.4 & -3.2 \\
LAS 19 & calcite & -13.5 & -10.1 & -11.7 & -4.5 & -0.8 & -2.8 \\
\hline
\end{tabular}

As Table 1 shows, the SQ samples are characterized by different values regarding both $\delta^{18} \mathrm{O}$ and $\delta^{13} \mathrm{C}$. The two flowstones dominated by aragonite (LAS 34 and LAS 72) exhibit higher isotope values, while the calcite samples from $\mathrm{KO}$ are characterized by the lowest $\delta^{13} \mathrm{C}$ values.

The majority of the flowstones do not exhibit a correlation $\left(R^{2}<0.60\right)$ between $\delta^{13} \mathrm{C}$ and $\delta^{18} \mathrm{O}$ values, with the exception of three samples (LAS 2, LAS 34 and LAS 72) that show a significant correlation between the two isotopes with slopes of regression varying from 2.5 to 3.4 (Fig. 3). The crystal fabric of these samples is dominated by acicular aragonite. In LAS 2 the covariance of $\delta^{13} \mathrm{C}$ and $\delta^{18} \mathrm{O}$ is characterized by almost identical slopes of the regression lines for both aragonite $\left(\delta^{13} \mathrm{C}=2.7 \times \delta^{18} \mathrm{O}+32.4, R^{2}=0.79\right)$ and calcite $\left(\delta^{13} \mathrm{C}=2.9 \times \delta^{18} \mathrm{O}+35.2, R^{2}=0.60\right.$; Fig. 3a). On the contrary, LAS 1 does not show any covariance for calcite $\left(R^{2}=0.33\right)$ and aragonite $\left(R^{2}=0.13\right)$. The number of stable isotopes analyses $(n=7)$ in the aragonite of LAS 21 was too small to investigate the relationship of $\delta^{13} \mathrm{C}$ and $\delta^{18} \mathrm{O}$ variability.

Carbon isotope values mostly follow the first-order changes of oxygen isotopes in all samples except LAS 1 . However, the relationship between the two isotopes may vary within a given sample. In LAS 6 and LAS 21 this relationship breaks down in the 13 and $7 \mathrm{~mm}$ dft respectively, while in LAS 19 rising $\delta^{18} \mathrm{O}$ values correspond to decreasing $\delta^{13} \mathrm{C}$ levels from 66 to $54 \mathrm{~mm}$ (dft). 

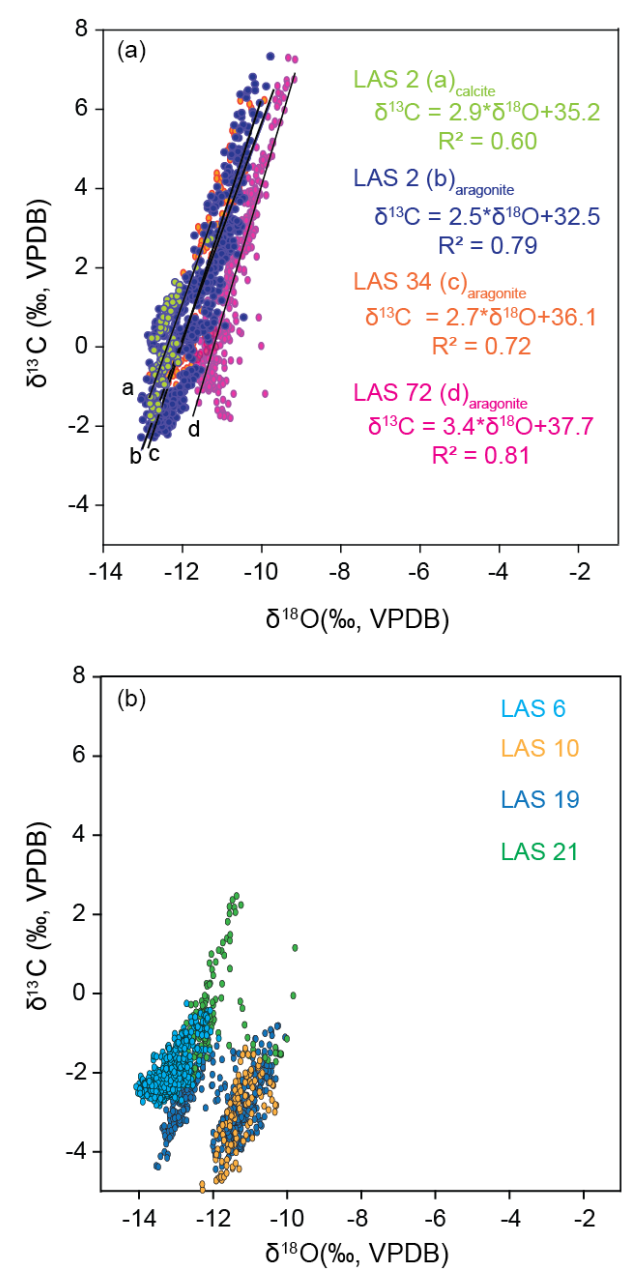

Figure 3. (a) Isotope crossplot for samples LAS 2, LAS 34 and LAS 72 . The highly significant correlation $\left(R^{2} \geq 0.60\right)$ between the two isotopes suggests strong disequilibrium-controlled isotope fractionation. (b) Calcite samples only show a weak correlation between $\delta^{18} \mathrm{O}$ and $\delta^{13} \mathrm{C}\left(R^{2}<0.60\right)$.

Major changes in $\delta^{18} \mathrm{O}$ values are observed in LAS 2 and LAS 19. The former sample exhibits generally high oxygen isotope values in the aragonite growth phase from the bottom until $50 \mathrm{~mm}(\mathrm{dft})$, interrupted by periods of lower $\delta^{18} \mathrm{O}$ values. A $0.8 \%$ decrease is seen between 74 and $72 \mathrm{~mm}(\mathrm{dft})$ coinciding with the presence of a calcite layer. A gradual shift of $2.2 \%$ o towards lower values is observed from 52 to $47 \mathrm{~mm}(\mathrm{dft})$ and is independent of the fabric, while a $1.6 \%$ rise in $\delta^{18} \mathrm{O}$ characterises the calcite from 17 to $14 \mathrm{~mm}$ (dft). In LAS 19 a significant $3.2 \%$ shift towards more positive $\delta^{18} \mathrm{O}$ values occurs from 66 to $54 \mathrm{~mm}$ (dft), followed by a decrease in carbon isotope values. Moreover, in all samples $\delta^{18} \mathrm{O}$ values show high-frequency changes of different amplitude ( 0.5 to $1.5 \%$ ), while no major trend is observed.

\subsection{Chronology}

The Vinschgau samples show exceptionally high ${ }^{238} \mathrm{U}$ concentrations, ranging from ca. 1.5 to $1200 \mathrm{ppm}$ (Table 1) and are among the most U-rich speleothems ever reported (Spötl et al., 2002; Kelly et al., 2003). $\delta^{234} \mathrm{U}$ ranges from 7 to $100 \%$. The ${ }^{232} \mathrm{Th}$ content is highly variable and fluctuates between $61 \mathrm{ppt}$ and $178 \mathrm{ppb}$ (Table S1). Except for three subsamples of LAS 19 all samples show high ${ }^{230} \mathrm{Th} /{ }^{232} \mathrm{Th}$ activity ratios, and thus excess ${ }^{230} \mathrm{Th}$ has no significant influence on the final ages.

Of the 77 total dates measured, 74 are in stratigraphic order within their $2 \sigma$ uncertainties. The three dated offsets (from samples L6-54, L6-79 and L1-38.5) are 5, 2 and 60 years beyond stratigraphic order respectively (Table S1). As these differences represent less than 0.5, 0.25 and $\sim 2 \%$ o age deviation for L6-54, L6-79 and LAS 34 respectively, we do not consider these ages as outliers and include them in the age models (Figs. S1-S2).

LAS 1 formed between $12.99 \pm 0.05$ and $12.01 \pm 0.03 \mathrm{ka}$, while LAS 2 grew uninterruptedly between $14.18 \pm 0.03$ and $12.12 \pm 0.03 \mathrm{ka}$. The last sample from the TR site, LAS 21 initiated deposition at $12.28 \pm 0.03$ and grew continuously until $11.68 \pm 0.02 \mathrm{ka}$ (Figs. S2-S3).

LAS 6 from the SQ site formed between $12.06 \pm 0.04$ and $11.68 \pm 0.03 \mathrm{ka}$. Similarly to LAS 2 , growth of LAS $34 \mathrm{com}-$ menced $14.18 \pm 0.03 \mathrm{ka}$ and ended at $12.54 \pm 0.03 \mathrm{ka}$, showing no major growth interruptions. LAS 72 provides a record between $11.64 \pm 0.04$ and $10.03 \pm 0.03 \mathrm{ka}$. The age model of LAS 72 shows that there may have been a hiatus from 10.54 to $10.30 \mathrm{ka}$ (modelled ages) corresponding to 13 to $14 \mathrm{~mm}$ on the depth scale (Fig. S3d). However, as thin-section analysis provided no evidence for a growth interruption (e.g. corrosion layer) we attribute this to an interval of slow growth rates.

The U-Th dates of the studied section of LAS 10 range from $9.94 \pm 0.03$ to $10.21 \pm 0.06 \mathrm{ka}$, while LAS 19 started to form in the Younger Dryas (YD) at $11.98 \pm 0.05 \mathrm{ka}$ and stopped growing in the early Holocene at $10.78 \pm 0.04 \mathrm{ka}$ (Figs. S2-S3).

\section{Discussion}

\subsection{Stable isotope systematics}

\section{$5.1 .1 \quad \delta^{18} \mathrm{O}$}

In karstic settings, speleothem $\delta^{18} \mathrm{O}$ values depend on the $\delta^{18} \mathrm{O}$ composition of drip water and on the cave air temperature, the latter influencing water-carbonate fractionation factors for both calcite and aragonite (e.g. McDermott, 2004; Lachniet, 2015). Modern spring monitoring in the Vinschgau suggests that the speleothem-forming waters are part of a larger groundwater system recharging at an elevation ranging from about 1200 to 2100 ma.s.l. Minimal variation in stable isotope composition and low tritium content point 
to long mean residence times of up to several decades (Spötl et al., 2002).

LAS 6 exhibits annual petrographic and geochemical lamination. Stable isotope analyses and heat-transfer modelling indicate that its $\delta^{18} \mathrm{O}$ oscillations are dominated by surface temperature changes transmitted to the subsurface via heat conduction (Koltai et al., 2017). Although $\delta^{18} \mathrm{O}$ provides a proxy for seasonal fluctuations in surface temperature (Koltai et al., 2017), its variability on a multi-annual timescale is well replicated by LAS 19, implying that the two flowstones were deposited close to isotopic equilibrium (Dorale and Liu, 2009).

As the well-developed petrographic lamination is due to traces of varying amounts of humic and fulvic acids, the lack of such regular laminae can be used as an indirect proxy for the depth of a given fracture. Thus we assume that nonlaminated flowstones formed at greater depths and the temperature in these subsurface fractures most likely reflect the outside mean annual air temperature. Spötl et al. (2002) reported that none of the nearby perennial springs showed intra-annual temperature variability, supporting this assumption. The water temperature of such a spring at the SQ site was constant $\left(12.8 \pm 0.1^{\circ} \mathrm{C}\right)$ during the 2-year monitoring period. Water dripping from the slope breccia at KO, however, showed $3.7^{\circ} \mathrm{C}$ variability (Spötl et al., 2002), which can be explained by the seasonal influence of the outside air. As we assume that the fractures were not influenced by seasonal changes in air temperature the $\delta^{18} \mathrm{O}$ signal of the Vinschgau flowstones is primarily regarded as a proxy for $\delta^{18} \mathrm{O}$ of groundwater and local precipitation. In mid- and high latitudes a well-established relationship exists between air temperature and the oxygen isotopic composition of precipitation; i.e. a temperature rise of $1{ }^{\circ} \mathrm{C}$ leads to $0.59 \pm 0.09 \%$ o higher isotope values (Rozanski et al., 1992). This is partially counterbalanced in the speleothem $\delta^{18} \mathrm{O}$ signal by the isotope fractionation during calcite/aragonite formation. The temperature dependence of the oxygen isotope fractionation during calcite precipitation is $-0.24 \% 0^{\circ} \mathrm{C}^{-1}$ based on experimental studies (Kim and O'Neil, 1997), while a somewhat higher value $\left(-0.18 \% 0^{\circ} \mathrm{C}^{-1}\right)$ was determined by a cave-based study (Tremaine et al., 2011). Kim et al. (2007) reported a similar value $\left(-0.22 \% 0^{\circ} \mathrm{C}^{-1}\right)$ for the temperature coefficient for the oxygen isotope fractionation of aragonite. Consequently, for the study area a positive (negative) net isotope change is expected in the speleothem $\delta^{18} \mathrm{O}$ signal during climate amelioration (deterioration). This signal, however, may be modified to a variable extent by in-aquifer processes as discussed in 5.2 .

\section{$5.1 .2 \delta^{13} \mathrm{C}$}

The interpretation of the carbon isotope signal of speleothems from karst caves is commonly more challenging than that of $\delta^{18} \mathrm{O}$ (e.g. McDermott, 2004), since $\delta^{13} \mathrm{C}$ values can be affected by a variety of processes in- cluding carbon dynamics of the soil and epikarst, subsurface air ventilation and associated disequilibrium isotope fractionation. Today, the Sonnenberg slope is mainly covered by sandy pararendzinas (Florineth, 1974) and contains semi-arid vegetation. The strong soil moisture deficit on the slopes (Della Chiesa et al., 2014) may limit the amount of solutes entering the fracture system (Fairchild and Baker, 2012). Additionally, some of the carbonate is derived from the crystalline host rock, in particular local occurrences of Fe carbonates (Spötl et al., 2002).

Although carbon isotopes mostly follow the fluctuations of $\delta^{18} \mathrm{O}$, this relationship can vary within a given sample (e.g. LAS 19). LAS 19 shows a $\delta^{18} \mathrm{O}$ rise of $3.2 \%$ at the YDHolocene transition, followed by a similar decrease in carbon isotopes (Fig. S4), suggesting that during certain time intervals carbon isotopes may reflect a soil signal, where lower $\delta^{13} \mathrm{C}$ values correspond to an increase in soil bioproductivity (Genty et al., 2001; Fairchild and Baker, 2012; Borsato et al., 2015). As discussed below this signal is, however, masked by in-aquifer processes.

\subsection{Internal aquifer processes}

In a subsurface fracture system like the Sonnenberg where speleothems form as vein-filling calcite and aragonite, prior calcite precipitation (PCP) and/or prior aragonite precipitation (PAP) are expected to influence the carbon isotope composition of speleothems (e.g. Fairchild and Baker, 2012). However, recent laboratory experiments indicate that PCP has an effect on the oxygen isotope systematics of the precipitating calcite as well (Polag et al., 2010; Dreybrodt and Scholz, 2011). Thus we propose that PCP may lead to progressively higher oxygen isotope values along the flow path, even if this change is of much smaller amplitude than that of $\delta^{13} \mathrm{C}$. Although similar experiments investigating the influence of PAP on the stable isotope composition of the precipitating aragonite are lacking, a simultaneous enrichment in ${ }^{13} \mathrm{C}$ and ${ }^{18} \mathrm{O}$ may be expected. Evaporation-induced disequilibrium fractionation is also likely to have an effect on the stable isotope values of calcite and aragonite flowstones since evaporation and associated $\mathrm{CO}_{2}$ degassing are the primary drivers of secondary carbonate deposition. Evaporation exerts significant control on oxygen isotope values, resulting in the enrichment of ${ }^{18} \mathrm{O}$ in the remaining water and consequently higher $\delta^{18} \mathrm{O}$ levels in the calcite/aragonite, while $\mathrm{CO}_{2}$ degassing affects carbon levels. Stable isotope and temperature monitoring of a shallow underground pool and its associated actively forming calcite speleothem indicates that calcite precipitation occurs close to isotopic equilibrium with respect to $\delta^{18} \mathrm{O}$, while $\delta^{13} \mathrm{C}$ levels strongly deviate from equilibrium (Spötl et al., 2002). This is also supported by the fact that even though carbon and oxygen isotopes show a covariance in several flowstones, calcite samples and LAS 1 do not exhibit co-varying $\delta^{13} \mathrm{C}$ and $\delta^{18} \mathrm{O}$ values. Similarities in the absolute $\delta^{18} \mathrm{O}$ values of the three TR samples (LAS 1, LAS 2 


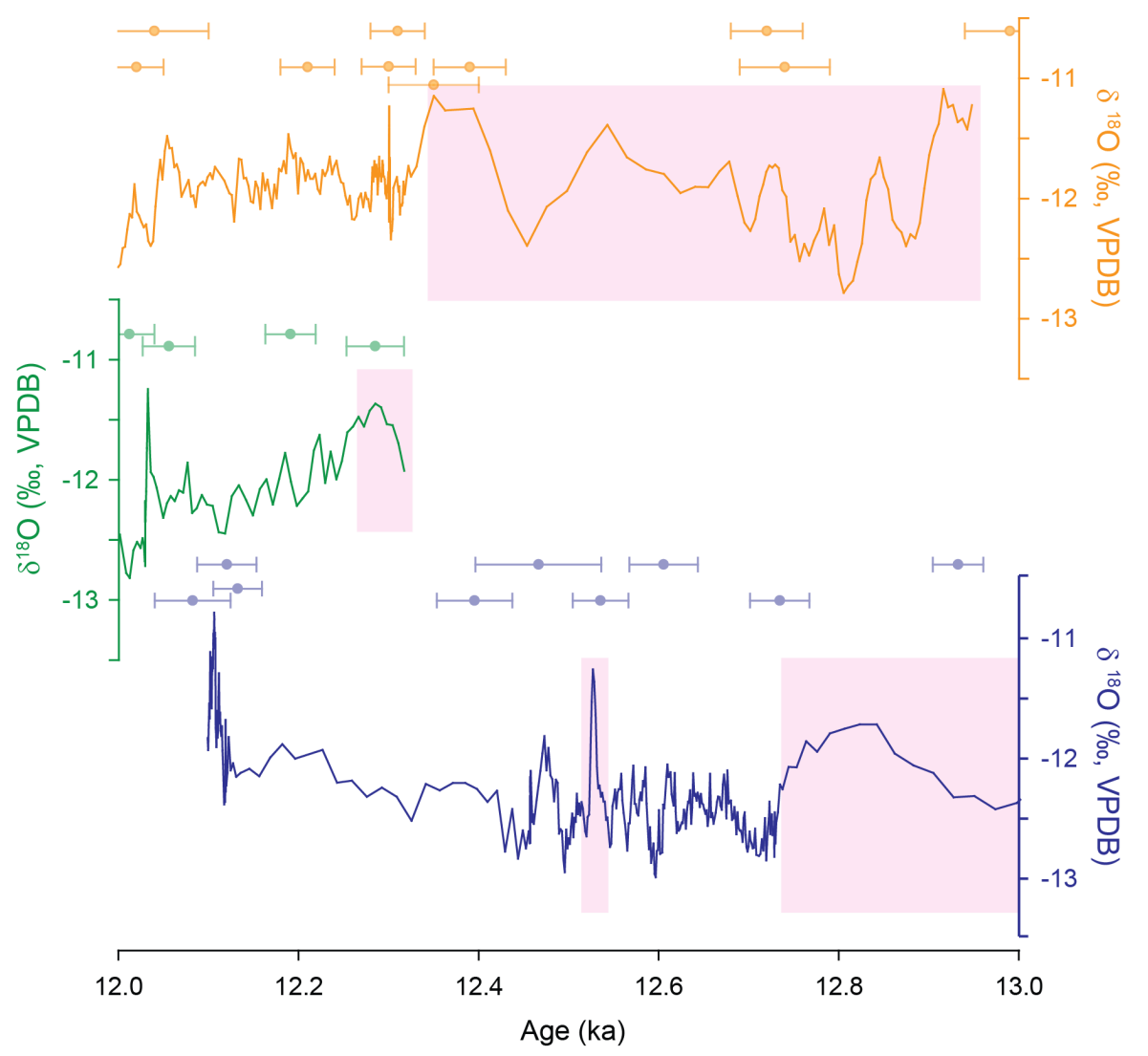

Figure 4. $\delta^{18} \mathrm{O}$ variability of the TR samples LAS 1 (orange), LAS 21 (green) and LAS 2 (blue) in their overlapping sections. All samples are plotted based on the modelled ages. ${ }^{230} \mathrm{Th}$ ages with their corresponding errors are plotted above each $\delta^{18} \mathrm{O}$ time series. Pink rectangles indicate aragonite fabric.

and LAS 21) further corroborate this, suggesting that despite $\mathrm{PCP} / \mathrm{PAP}$ occurrence along the flow path, flowstone precipitation occurred close to isotopic equilibrium. Therefore, we propose that disequilibrium fractionation likely had a negligible influence on the $\delta^{18} \mathrm{O}$ of speleothem calcite.

In contrast, given that $\delta^{13} \mathrm{C}$ and $\delta^{18} \mathrm{O}$ values co-vary in the aragonite samples (LAS 34 and LAS 72) and also in LAS 2 independent of its mineralogy (Fig. 3), these samples may have formed out of isotopic equilibrium. Although the covariance of carbon and oxygen isotope values may result from in-aquifer processes, it has been widely used as an indicator of disequilibrium isotope fractionation (Hendy, 1971). The slope of regression of $\Delta \delta^{13} \mathrm{C} / \Delta \delta^{18} \mathrm{O}$ varies between 2.5 and 3.4 in LAS 2, 24 and 72 (Fig. 3a). Such values indicate that disequilibrium isotope fractionation occurred during aragonite precipitation, whereby $\mathrm{CO}_{2}$ hydration and hydroxylation reactions promoting oxygen isotope exchange between $\mathrm{HCO}_{3}$ reservoir and $\mathrm{H}_{2} \mathrm{O}$ were not fast enough to maintain isotopic equilibrium (Mickler et al., 2006). The lack of a similarly strong correlation between the two isotopes in the flowstone samples dominated by calcite (Fig. 3b), except for LAS 2, further supports the influence of disequilibrium isotope effects over that of in-aquifer processes. As none of these springs are presently precipitating aragonite, it is hard to distinguish whether evaporation and PCP/PAP or disequilibrium isotope fractionation, or a combination of these processes, led to the covariation between $\delta^{18} \mathrm{O}$ and $\delta^{13} \mathrm{C}$ in the flowstones.

To further analyse the potential influence of disequilibrium processes and local hydrology on the isotopic composition of the Vinschgau flowstones, coeval sections were compared. Unfortunately, in all cases the common time window of deposition is too short to provide reliable analyses using statistical methods (e.g. Fohlmeister, 2012). Nevertheless, as the deposition of the three TR samples partly overlaps, intrafracture variability can be tested on decadal-to-centennial scales despite differences in growth rate and hence proxy data resolution. Given the similarities in the range of $\delta^{18} \mathrm{O}$ variability (Fig. 4), mineralogy, and in the lack of fluorescent lamination, we suggest that flowstones in a given fracture form under very similar conditions and therefore most probably record the local climate signal. Differences in the absolute values of $\delta^{18} \mathrm{O}$ and $\delta^{13} \mathrm{C}$ are attributed to PAP and PCP.

A stronger influence of the local hydrology and hence a lower climate signal / noise ratio is expected when compar- 


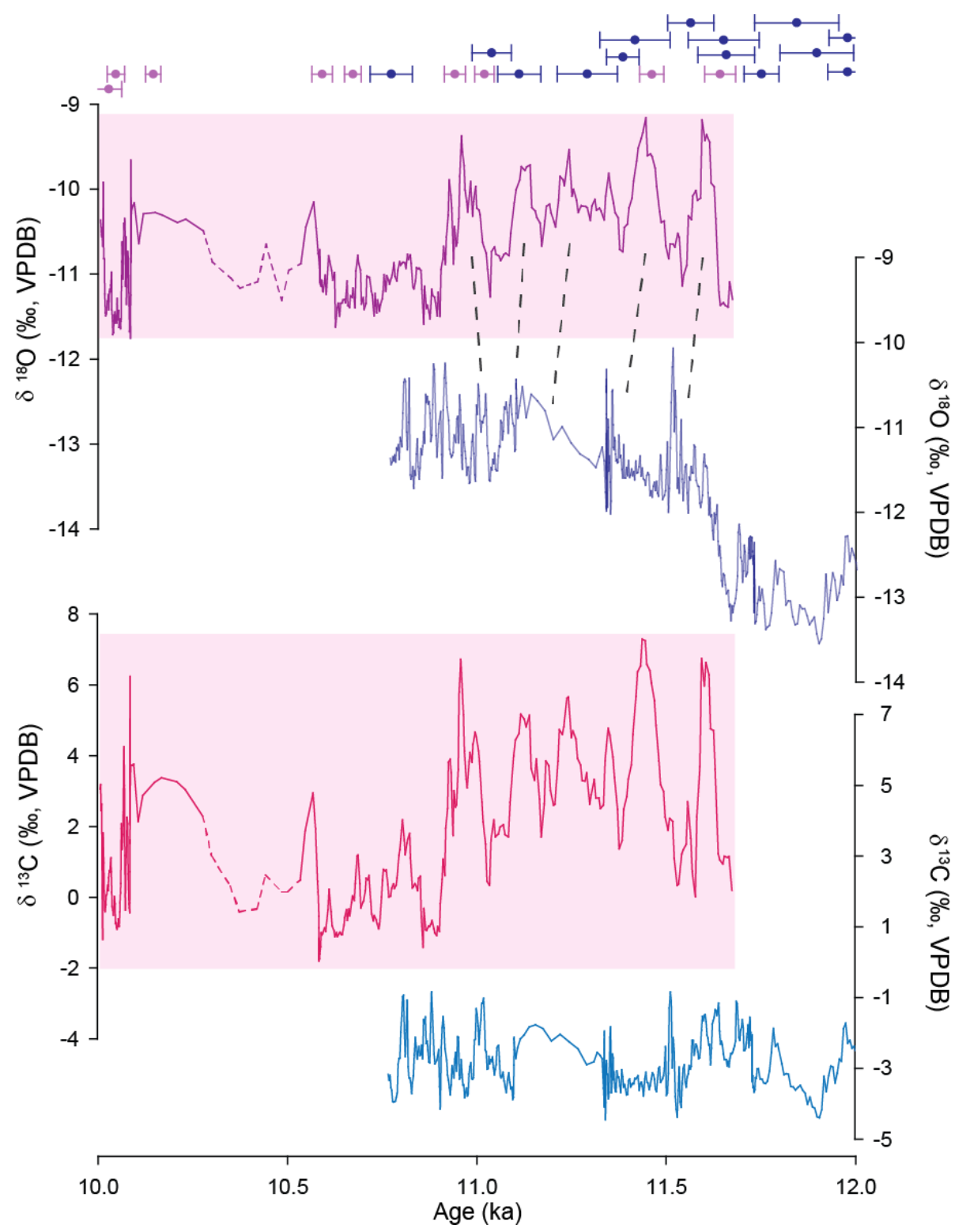

Figure 5. Stable isotope variability of LAS 72 (pink) and LAS 19 (blue) between 12 and $10 \mathrm{ka}$. Dashed lines in the stable isotope time series of LAS 72 represent the period characterized by slow growth rate. Dashed tie lines indicate similarities between the $\delta^{18} \mathrm{O}$ variability of the two flowstones. Note that LAS 72 is comprised of aragonite as indicated by the pink rectangle, while LAS 19 is a calcitic flowstone.

ing flowstones from different sites (Fig. 5). Due to the interfracture variance in PCP/PAP, calcite was deposited at KO (sample LAS 19), while at the same time aragonite formed at the SQ site (sample LAS 72). Still, their $\delta^{18} \mathrm{O}$ pattern shares some similarities within the combined errors of the two age models, while $\delta^{13} \mathrm{C}$ in the aragonite specimen shows a much larger amplitude $(8.9 \%$ ) than in the coeval calcitic one $(3.6 \%)$. This most likely reflects the combined influence of disequilibrium isotopic fractionation and the difference in the fractionation factor between the two polymorphs (Morse and Mackenzie, 1990; Frisia et al., 2002). Frisia et al. (2002) reported that carbon isotopes are 2 to $3.4 \%$ higher in arago- nite than in calcite at Grotte de Clamouse (southern France). $\delta^{13} \mathrm{C}$ values similar to that of LAS 72 were reported from modern aragonite from Obstanser Eishöhle (2.4 to 7.0\%o), an alpine cave in southern Austria (Spötl et al., 2016). Moreover, PCP (PAP) may have further increased the $\delta^{13} \mathrm{C}$ values in the Vinschgau sites.

\subsection{Potential as a palaeoclimate archive}

Similar to speleothems from karst caves in semiarid settings (e.g. Avigour et al., 1992; McMillan et al., 2005; Hoffmann et al., 2016), fracture-filling flowstone from non- 

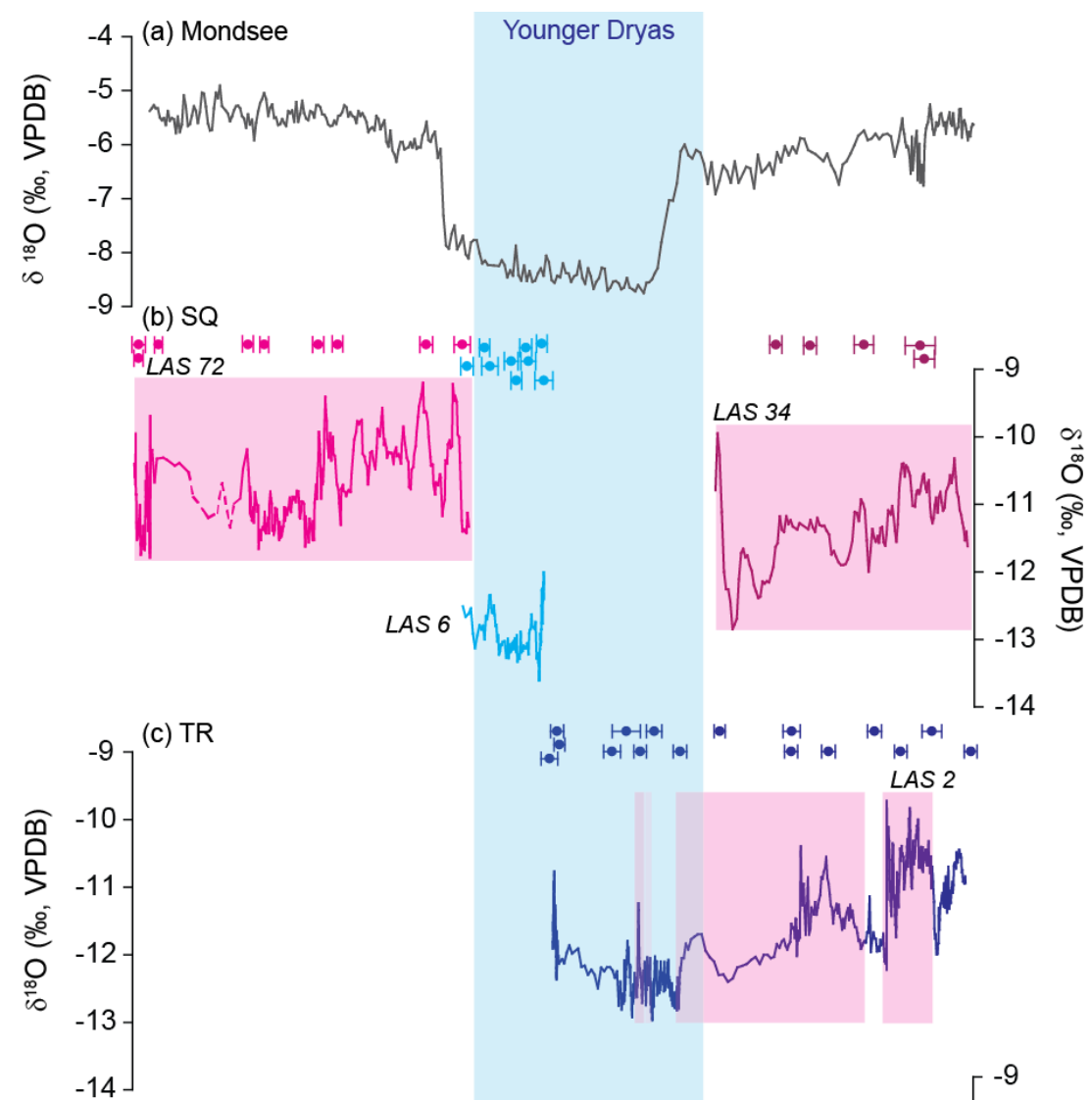

(d) TR
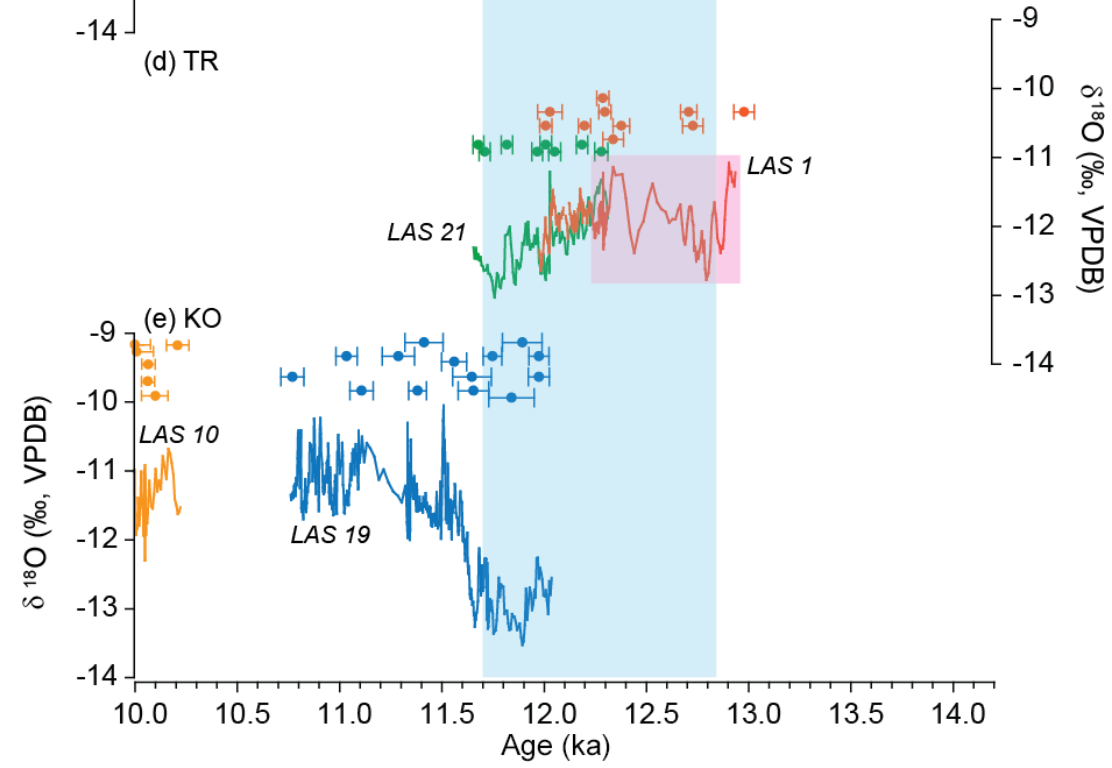

Figure 6. Comparison of $\delta^{18} \mathrm{O}$ time series of (a) benthic ostracods from Mondsee (Lauterbach et al., 2011) and the Vinschgau flowstones (be). (b) shows the three samples from SQ site: LAS 72 (bright pink), LAS 6 (turquoise) and LAS 34 (dark pink). The $\delta^{18} \mathrm{O}$ variability of the TR samples is shown in (c) and (d), where dark blue represents LAS 2, green and orange mark the oxygen isotope record of LAS 21 and LAS 1 respectively. LAS 10 (yellow) and LAS 19 (light blue) from KO are shown in (e). Note that the pink rectangles are indicative of aragonite and the blue bar refers to the Younger Dryas. 
carbonate, climate-sensitive settings may provide a useful record of palaeoaridity and palaeohydrology. Annually laminated flowstones (e.g. LAS 6) that formed at a few metres depth may provide insights into changes in seasonality (Koltai et al., 2017), while those from deeper fractures likely record changes at multi-decadal-to-centennial resolution and thus provide a fragmented archive of local climate history. This case study shows, however, that fracture-filling speleothems also record the inherent heterogeneity of such fractured aquifers, which may mask short-term climate signals.

As aragonite is metastable at Earth's surface conditions and hence susceptible to diagenetic transformation, the possible alteration of the geochemical signal has to be considered (e.g. Domínguez-Villar et al., 2017 and references therein). Moreover, Lachniet (2015) emphasized that the $\delta^{18} \mathrm{O}$ variability of aragonite speleothems should only be used as a proxy if aragonite precipitation occurred close to isotopic equilibrium. Thin section and XRD analyses indicate pristine aragonite in $\operatorname{LAS} 1,2,34$ and 72. Aragonite preservation in these samples is further supported by the fact that all ${ }^{230} \mathrm{Th}$ ages are in stratigraphic order regardless of mineralogy (Table S1). Nevertheless, flowstone deposition was most probably influenced by disequilibrium isotope fractionation as suggested by the high correlation between carbon and oxygen isotopes in LAS 2, 34 and 72 (Fig. 3). Therefore, $\delta^{18} \mathrm{O}$ variability should be interpreted carefully in these three samples.

Moreover, the timing of aragonite deposition does not show any systematic relationship between the samples during the Late Glacial and the early Holocene (Figs. 4-6). Instead petrographic analyses and hydrochemistry data of modern springs (Spötl et al., 2002) suggest that due to the high degree of total dissolved solids only small changes in water chemistry give rise to either aragonite or calcite precipitation, partly reflecting the heterogeneity of the fractured aquifer. Similarly, changes in growth rate are first and foremost driven by in-aquifer processes including PCP and/or PAP, as indicated by the TR samples (Fig. 4). Therefore, calcite-aragonite transitions and growth rate changes do not necessarily reflect an external (climate) signal, unless coeval samples show a coherent pattern.

Carbon isotope data suggest a weak soil-derived signal for short time periods only (e.g. at the YD-Holocene transition in LAS 19; Fig. S4), while most values suggest buffering by inorganic carbon in conjunction with kinetic isotope enrichment (Spötl et al., 2002).

The most prominent feature of $\delta^{18} \mathrm{O}$ proxy record is the $\sim 3.2 \%$ rise in LAS 19 at the YD-Holocene transition (Fig. 6e). Moreover, the first-order pattern of the two aragonite samples covering the Bølling-Allerød warm phase shows close resemblance to the $\delta^{18} \mathrm{O}$ variability of the ostracod record from Mondsee (Lauterbach et al., 2011), a lake in central Austria, suggesting that centennial-to-orbital-scale large-amplitude changes of the Northern Hemisphere climate system are recorded in the $\delta^{18} \mathrm{O}$ variability of this archive.

During the YD a gradual $\sim 1.7 \%$ o decline in $\delta^{18} \mathrm{O}$ is observed in LAS 21 between 12.2 and $11.7 \mathrm{ka}$. Parts of this shift are also captured by LAS 1 and LAS 19, implying a related cause. Several terrestrial archives across Europe record a change in regional climate mid-way through the YD (e.g. Brauer et al., 2008; Bakke et al., 2009; Baldini et al., 2015; Belli et al., 2017). The onset of this transition was time-transgressive ( $\sim 12.45$ to $12.15 \mathrm{ka})$ across Europe due to the gradual northward shift of the polar front driven by the resumption of the North Atlantic overturning (Lane et al., 2013; Bartolomé et al., 2015). Whether this shift towards lower values in our $\delta^{18} \mathrm{O}$ record corresponds to the change in the regional climate or to in-aquifer processes remains unclear given the lack of flowstone samples covering the entire YD.

\section{Conclusions}

Petrographic and geochemical analyses of vein-filling calcite and aragonite flowstones in near-surface fractures indicate that the latter polymorph is more susceptible to disequilibrium processes regarding both $\delta^{18} \mathrm{O}$ and $\delta^{13} \mathrm{C}$. The two most important in-aquifer processes modifying the geochemical signature of these speleothems are evaporation and PCP/PAP. Both of these processes are likely to govern variations in speleothem mineralogy, as indicated by the deposition of coeval aragonite and calcite flowstones. Accordingly, changes in speleothem mineralogy cannot be used to constrain the timing of past episodes of high vs. low precipitation in the Vinschgau.

$\delta^{18} \mathrm{O}$ variability has been proven to be the most reliable climate proxy in the Vinschgau flowstones. Low-amplitude, high-frequency (decadal-scale) variability in LAS 1, 6, 10, 19 and 21 is attributed to in-aquifer processes, while the centennial-scale variability shows significant variation (e.g. $3.2 \%$ ) suggesting changes in the $\delta^{18} \mathrm{O}$ of precipitation. Although local factors, such as strong evaporation and PCP/PAP can amplify these climate signatures, the $\delta^{18} \mathrm{O}$ values show a broadly similar pattern to regional $\delta^{18} \mathrm{O}$ lacustrine records (e.g. Mondsee).

Due to the lack of long overlapping sections of speleothem growth and the complexity of in-aquifer processes this case study shows that it is highly challenging to establish a robust stacked $\delta^{18} \mathrm{O}$ record of local climate change on multimillennial to orbital timescales using such speleothems. However, it is possible that fracture-filling calcite and/or aragonite from other areas have great potential as a climate archive if the local hydrogeological conditions are well constrained. Our study also emphasises that tight age control and a multi-proxy approach are essential for the study of such non-karstic settings. 
Data availability. Stable isotope data reported in this article is available upon request from the authors.

Supplement. The supplement related to this article is available online at: https://doi.org/10.5194/cp-14-369-2018-supplement.

Competing interests. The authors declare that they have no conflict of interest.

Acknowledgements. This project was supported by the Autonome Provinz Bozen-Südtirol (no. 16/40.3). Daniela Schmidmair is acknowledged for XRD analyses and Kathleen Wendt for linguistic help and valuable comments. We thank Ian J. Fairchild, Dana C. Riechelmann and an anonymous reviewer for constructive and thorough comments that greatly helped to improve the manuscript.

Edited by: Marit-Solveig Seidenkrantz

Reviewed by: Ian J. Fairchild, Dana Riechelmann, and one anonymous referee

\section{References}

Avigour, A., Magaritz, M., and Issar, A.: Pleistocene paleoclimate of the arid region of Israel as recorded in calcite deposits along regional transverse faults and in veins, Quaternary Res., 37, 304314, 1992.

Bakke, J., Lie, O., Heegaard, E., Dokken, T., Haug, G. H., Birks, H. H., Dulski, P., and Nilsen, T.: Rapid oceanic and atmospheric changes during the Younger Dryas cold period, Nat. Geosci., 2, 202-205, 2009.

Baldini, L. M., McDermott, F., Baldini, J. U. L., Arias, P., Cueto, M., Fairchild, I. J., Hoffmann, D. L., Mattey, D. P., Müller, W., Nita, D. C., Ontanón, R., Garciá-Moncó, C., and Richards, D. A.: Regional temperature, atmospheric circulation, and sea ice variability within the Younger Dryas Event constrained using a speleothem from northern Iberia, Earth Planet. Sc. Lett., 419, 101-110, 2015.

Bartolomé, M., Moreno, A., Sancho, C., Stoll, H. M., Cacho, I., Spötl, C., Belmonte, Á., Edwards, R. L., Cheng, H., and Hellstrom, J. C.: Hydrological change in Southern Europe responding to increasing North Atlantic overturning during Greenland Stadial 1, P. Natl. Acad. Sci. USA, 112, 6568-6572, 2015.

Belli, R., Borsato, A., Frisia, S., Drysdale, R., Maas, R., and Greig, A.: Investigating the hydrological significance of stalagmite geochemistry $(\mathrm{Mg}, \mathrm{Sr})$ using $\mathrm{Sr}$ isotope and particulate element records across the Late Glacial-to-Holocene transition, Geochim. Cosmochim. Ac., 199, 247-263, 2017.

Boch, R., Cheng, H., Spötl, C., Edwards, R. L., Wang, X., and Häuselmann, Ph.: NALPS: a precisely dated European climate record 120-60 ka, Clim. Past, 7, 1247-1259, https://doi.org/10.5194/cp-7-1247-2011, 2011.

Borsato, A., Frisia, S., and Miorandi, R.: Carbon dioxide concentration in temperate climate caves and parent soils over an altitudi- nal gradient and its influence on speleothem growth and fabrics, Earth Surf. Proc. Land., 40, 1158-1170, 2015.

Brauer, A., Haug, G. H., Dulski, P., Sigman, D. M., and Negendank, J. F. W.: An abrupt wind shift in western Europe at the onset of the Younger Dryas cold period, Nat. Geosci., 1, 520-523, 2008.

Cheng, H., Edwards, R. L., Shen, C.-C., Polyak, V. J., Asmerom, Y., Woodhead, J., Hellstrom, J., Wang, Y., Kong, X., Spötl, C., Wang, X., and Calvin Alexander Jr., E.: Improvements in ${ }^{230} \mathrm{Th}$ dating, ${ }^{230} \mathrm{Th}$ and ${ }^{234} \mathrm{U}$ half-life values, and U-Th isotopic measurements by multi-collector inductively coupled plasma mass spectrometry, Earth Planet. Sc. Lett., 371, 82-91, 2013.

Cheng, H., Edwards, R. L., Sinha, A., Spötl, C., Yi, L., Chen, S., Kelly, M., Kathayat, G., Wang, X., Li, X., Kong, X., Wang, Y., Ning, Y., and Zhang, H.: The Asian monsoon over the past 640000 years and ice age terminations, Nature, 534, 640-646, 2016.

Della Chiesa, S., Bertoldi, G., Niedrist, G., Obojes, N., Endrizzi, S., Albertson, J. D., Wohlfahrt, G., Hörtnagl, L., and Tappeiner, U.: Modelling changes in grassland hydrological cycling along an elevational gradient in the Alps, Ecohydrology, 7, 1453-1473, 2014.

Domínguez-Villar, D., Krklec, K., Pelicon, P., Fairchild, I. J., Cheng, H., and Edwards, L. R.: Geochemistry of speleothems affected by aragonite to calcite recrystallization - potential inheritance from the precursor mineral, Geochim. Cosmochim. Ac., 200, 310-329, 2017.

Dorale, J. A. and Liu, Z- H.: Limitations of Hendy test criteria in judging the paleoclimatic suitability of speleothems and the need for replication, J. Cave Karst Stud., 71, 73-80, 2009.

Dreybrodt, W. and Scholz, D.: Climatic dependence of stable carbon and oxygen isotope signals recorded in speleothems: from soil water to speleothem calcite, Geochim. Cosmochim. Ac., 75, 734-752, 2011.

Edwards, R. L., Chen, J. H., and Wasserburg, G. J.: ${ }^{238}$ U, ${ }^{234} \mathrm{U}$, ${ }^{230} \mathrm{Th},{ }^{232} \mathrm{Th}$ systematics and the precise measurement of time over the past 500000 years, Earth Planet. Sc. Lett., 81, 171-192, 1987.

Fairchild, I. J. and Baker, A.: Speleothem science: from processes to past environments, Wiley-Blackwell, Oxford, 2012.

Fliri, F.: Das Klima der Alpen im Raume von Tirol, UniversitätsVerlag Wagner, Innsbruck, 1975.

Florineth, F.: Vegetation und Boden im Steppengebiet des oberen Vinschgaues (Südtirol, Italien), Naturwiss.-med. Verein Innsbruck Berichte, 61, 43-70, 1974.

Fohlmeister, J.: A statistical approach to construct composite climate records of dated archives, Quat. Geochronol., 14, 48-56, 2012.

Fohlmeister, J., Schröder-Ritzrau, A., Scholz, D., Spötl, C., Riechelmann, D. F. C., Mudelsee, M., Wackerbarth, A., Gerdes, A., Riechelmann, S., Immenhauser, A., Richter, D. K., and Mangini, A.: Bunker Cave stalagmites: an archive for central European Holocene climate variability, Clim. Past, 8, 1751-1764, https://doi.org/10.5194/cp-8-1751-2012, 2012.

Ford, D. C. and Williams, P. W.: Karst Geomorphology and Hydrology, Unwin Hyman, London, 2007.

Frisia, S.: Microstratigraphic logging of calcite fabrics in speleothems as tool for palaeoclimate studies, Int. J. Speleol., 44, $1-16,2015$. 
Frisia, S., Borsato, A., Fairchild, I. J., McDermott, F., and Selmo, E. M.: Aragonite-calcite relationships in speleothems (Grotte de Clamouse, France): environment, fabrics, and carbonate geochemistry, J. Sediment. Res., 72, 687-699, 2002.

Frisia, S., Borsato, A., Preto, N., and McDermott, F.: Late Holocene annual growth in three Alpine stalagmites records the influence of solar activity and the North Atlantic Oscillation on winter climate, Earth Planet. Sc. Lett., 216, 411-424, 2003.

Frisia, S., Weirich, L., Hellstrom, J., Borsato, A., Golledge, N. R., Anesio, A. M., Bajo, P., Drysdale, R. N., Augustinus, P. C., Rivard, C., and Cooper, A.: The influence of Antarctic subglacial volcanism on the global iron cycle during the Last Glacial Maximum, Nat. Commun., 8, 15425, https://doi.org/10.1038/ncomms15425, 2017.

Genty, D., Baker, A., Massault, M., Proctor, C., Gilmour, M., PonsBranchu, E., and Hamelin, B.: Dead carbon in stalagmites: carbonate bedrock paleodissolution vs. aging of soil organic matter. Implications for ${ }^{13} \mathrm{C}$ variations in speleothems, Geochim. Cosmochim. Ac., 65, 3443-3457, 2001.

Heiri, O., Koinig, K. A., Spötl, C., Barrett, S., Brauer, A., Drescher-Schneider, R., Gaar, D., Ivy-Ochs, S., Kerschner, H., Luetscher, M., Moran, A., Nicolussi, K., Preusser, F., Schmidt, R., Schoeneich, P., Schwörer, C., Sprafke, T., Terhorst, B., and Tinner, W.: Palaeoclimate records $60-8 \mathrm{ka}$ in the Austrian and Swiss Alps and their forelands, Quaternary Sci. Rev., 106, 186-205, 2014.

Hendy, C. H.: The isotopic geochemistry of speleothems (Part I). The calculation of the effects of different modes of formation on the isotopic composition of speleothems and their applicability as palaeoclimatic indicators, Geochim. Cosmochim. Ac., 35, 801824, 1971.

Hoffmann, D. L., Rogerson, M., Spötl, C., Luetscher, M., Vance, D., Osborne, A., Fello, N., and Moseley, G.: Timing and causes of North African wet phases during the last glacial period and implications for modern human migration, Sci. Rep.-UK, 6, 36367, https://doi.org/10.1038/srep36367, 2016.

Ilyashuk, B., Gobet, E., Heiri, O., Lotter, A. F., van Lewuwen, J. F. N., van der Knaap, W. O., Ilyashuk, E., Oberili, F., and Ammann, B.: Lateglacial environmental and climatic changes at the Maloja Pass, Central Swiss Alps, as recorded by chironomids and pollen, Quaternary Sci. Rev., 28, 1340-1353, 2009.

Ivy-Ochs, S., Kerschner, H., Reuther, A., Preusser, F., Heine, K., Maisch, M., Kubik, P. W., and Schlüchter, C.: Chronology of the last glacial cycle in the European Alps, J. Quaternary Sci., 23, 559-573, 2008.

Johnson, K. R., Hu, C., Belshaw, N. S., and Henderson, G. M.: Seasonal trace-element and stable isotope variations in a Chinese speleothem: the potential for high resolution paleomonsoon reconstruction, Earth Planet. Sc. Lett., 244, 394-407, 2006.

Kelly, S. D., Newville, M. G., Cheng, L., Kemner, K. M., Sutton, S. R., Fenter, P., Sturchio, N. C., and Spötl, C.: Uranyl incorporation in natural calcite, Environ. Sci. Technol., 37, 12841287, 2003.

Kendall, A. C.: Radiaxial fibrous calcite: a reappraisal, in: Carbonate cements, edited by: Schneidermann, N. and Harris, P. M., SEPM Spec. P., 36, 59-77, 1985.
Kerschner, H. and Ivy-Ochs, S.: Palaeoclimate from glaciers: examples from the Eastern Alps during the Alpine Lateglacial and early Holocene, Global Planet. Change, 60, 58-71, 2008.

Kerschner, H., Kaser, G., and Sailer, R.: Alpine Younger Dryas glaciers as palaeo-precipitation gauges, Ann. Glaciol., 31, 8084, 2000.

Kim, S.-T. and O'Neil, J. R.: Equilibrium and nonequilibrium oxygen isotope effects in synthetic carbonates, Geochim. Cosmochim. Ac., 61, 3461-3475, 1997.

Kim, S.-T., O’Neil, J. R., Hillarie-Marcell, C., and Mucci, A.: Oxygen isotope fractionation between synthetic aragonite and water: influence of temperature and $\mathrm{Mg}^{2+}$ concentration, Geochim. Cosmochim. Ac., 71, 4704-4715, 2007.

Koltai, G., Spötl, C., Luetscher, M., Barrett, S. J., and Müller, W.: The nature of annual lamination in carbonate flowstones from non-karstic fractures, Vinschgau (northern Italy), Chem. Geol., 457, 1-14, 2017.

Lachniet, M. S.: Are aragonite stalagmites reliable palaeoclimate proxies? Test for oxygen isotope time-series replication and equilibrium, Geol. Soc. Am. Bull., 127, 1521-1533, 2015.

Lachniet, M. S., Bernal, J. P., Asmerom, Y., and Polyak, V.: Uranium loss and aragonite-calcite age discordance in a calcitized aragonite stalagmite, Quat. Geochronol., 14, 26-37, 2012.

Lane, C. S., Brauer, A., Blockley, S. P. E., and Dulski, P.: Volcanic ash reveals time-transgressive abrupt climate change during the Younger Dryas, Geology, 41, 1251-1254, 2013.

Lauterbach, S., Brauer, A., Andersen, N., Danielopol, D. L., Dulski, P., Hüls, M., Milecka, K., Namiotko, T., Obremska, M., von Grafenstein, U., and Declakes participants: environmental responses to Lateglacial climatic fluctuations recorded in the sediments of pre-Alpine Lake Mondsee (northeastern Alps), J. Quaternary Sci., 26, 253-267, 2011.

Luetscher, M., Boch, R., Sodemann, H., Spötl, C., Cheng, H., Edwards, L. R., Frisia, S., Hof, F., and Müller, W.: North Atlantic storm track changes during the Last Glacial Maximum recorded by Alpine speleothems, Nat. Commun., 6, 6344, https://doi.org/10.1038/ncomms7344, 2015.

Luetscher, M., Hellstrom, J., Müller, W., Barrett, S., Dublyansky, Y., and Spötl, C.: A Younger Dryas temperature reconstruction from alpine speleothems, Geophys. Res. Abstr, 18, EGU2016-11602, available at: http://meetingorganizer.copernicus.org/EGU2016/ EGU2016-11602.pdf, 2016.

McDermott, F.: Palaeo-climate reconstruction from stable isotope variations in speleothems: a review, Quaternary Sci. Rev., 23, 901-918, 2004.

Magny, M., Guiot, J., and Schoellammer, P.: Quantitative Reconstruction of Younger Dryas to Mid-Holocene Paleoclimates at Le Locle, Swiss Jura, Using Pollen and Lake-Level Data, Quaternary Res., 56, 170-180, https://doi.org/10.1006/qres.2001.2257, 2001.

McMillan, E. A., Fairchild, I. J., Frisia, S., Borsato, A., and McDermott, F.: Annual trace element cycles in calcite-aragonite speleothems: evidence of drought in the western Mediterranean 1200-1100 yr BP, J. Quaternary Sci., 20, 423-433, 2005.

Mickler, P. J., Stern, L. A., and Banner, J. L.: Large kinetic isotope effects in modern speleothems, Geol. Soc. Am. Bull., 118, 65$81,2006$. 
Morse, J. W. and Mackenzie, F. T.: Geochemistry of Sedimentary Carbonates. Developments in Sedimentology, Elsevier, Amsterdam, 48, 1990.

Ostermann, M., Koltai, G., Spötl, C., and Cheng, H.: Deepseated gravitational slope deformations in the Vinschgau (northern Italy) and their association with springs and speleothems, Geophys. Res. Abstr., 18, EGU2016-9307, available at: https://meetingorganizer.copernicus.org/EGU2016/ EGU2016-9307.pdf, 2016.

Polag, D., Scholz, D., Mühlinghaus, C., Spötl, C., SchröderRitzrau, A., Segl, M., and Mangini, A.: Stable isotope fractionation in speleothems: laboratory experiments, Chem. Geol., 279, 31-39, 2010.

Polyak, V. J. and Asmerom, Y.: Late Holocene climate and cultural changes in the southwestern United States, Science, 294, 148$151,2001$.

Richards, D. and Dorale, J. A.: Uranium-series chronology and environmental applications of speleothems, in: Uranium-Series Geochemistry, edited by: Bourdon, B., Henderson, G., Lundstorm, C. C., and Turner, S., Rev. Mineral. Geochem., 52, 407460, 2003.

Richter, D., Neuser, R. D., Schreuer, J., Gies, A., and Immenhauser, A.: Radiaxial fibrous calcites: a new look at an old problem, Sediment. Geol., 239, 23-36, 2011.

Ridley, H. E., Asmerom, Y., Baldini, J. U. L., Breitenbach, S. F. M., Aquino, V. V., Prufer, K. M., Culleton, B. J., Polyak, V., Lechleitner, F. A., Kennett, D. J., Zhang, M., Marwan, N., Macpherson, C. G., Baldini, L. M., Xiao, T., Peterkin, J. L., Awe, J., and Haug, G. H.: Aerosol forcing of the position of the intertropical convergence zone since AD1550, Nat. Geosci., 8, 195-200, https://doi.org/10.1038/ngeo2353, 2015.

Rozanski, K., Araguás-Araguás, L., and Gonfiantini, R.: Relation between long-term trends in oxygen-18 isotope composition of precipitation and climate, Science, 258, 981-985, 1992.

Schimpf, D., Kilian, R., Kronz, A., Spötl, C., Wörner, G., Deininger, M., and Mangini, A.: The significance of chemical, isotopic and detrital components in three coeval stalagmites from the superhumid southernmost Andes $\left(53^{\circ} \mathrm{S}\right)$ as high-resolution paleo-climate proxies, Quaternary Sci. Rev., 30, 443-459, 2011.

Scholz, D. and Hoffmann, D.: ${ }^{230} \mathrm{Th} / \mathrm{U}$-dating of fossil corals and speleothems, Quat. Sci. J., 57, 52-76, 2008.

Scholz, D. and Hoffman, D.: StalAge - an algorithm designed for construction of speleothem age models, Quat. Geochronol., 6, 369-382, 2011.

Shen, C. C., Wu, C. C., Cheng, H., Edwards, R. L., Hsieh, YT., Gallet, S., Chang, C. C., Li, T. Y., Lam, D. D., Kano, A., Hori, M., and Spötl, C.: High-precision and high resolution carbonate ${ }^{230} \mathrm{Th}$ dating by MC-ICP-MS with SEM protocols, Geochim. Cosmochim. Ac., 99, 71-86, 2012.
Spötl, C.: Long-term performance of the Gasbench isotope ratio mass spectrometry system for the stable isotope analysis of carbonate microsamples, Rapid Commun. Mass Sp., 25, 1683$1685,2011$.

Spötl, C., Unterwurzacher, M., Mangini, A., and Longstaffe, F. J.: Carbonate speleothems in the dry, inneralpine Vinschgau valley, northernmost Italy: witnesses of changes in climate and hydrology since the Last Glacial Maximum, J. Sediment. Res., 72, 793 808, 2002.

Spötl, C., Fohlmeister, J., Cheng, H., and Boch, R.: Modern aragonite formation at near-freezing conditions in an alpine cave, Carnic Alps, Austria, Chem. Geol., 435, 60-70, 2016.

Tremaine, D. M., Froelich, P. N., and Wang, Y.: Speleothem calcite farmed in situ: modern calibration of $\delta^{18} \mathrm{O}$ and $\delta^{13} \mathrm{C}$ paleoclimate proxies in a continuously-monitored natural cave system, Geochim. Cosmochim. Ac., 75, 4929-4950, 2011.

von Grafenstein, U., Erlenkeuser, H., Brauer, A., Jouzel, J., and Johnsen, S. J.: A mid-European decadal isotope-climate record from 15500 to 5000 years BP, Science, 284, 1654-1657, 1999.

von Grafenstein, U., Belmecheri, S., Eicher, U., van Raden, U. J., Erlenkeuser, H., Andersen, N., and Ammann, B.: The oxygen and carbon isotopic signatures of biogenic carbonates in Gerzensee, Switzerland, during the rapid warming around 14685 years BP and the following interstadial, Palaeogeogr. Palaeocl., 391, 25-32, 2013.

Wang, P. X., Wang, B., Cheng, H., Fasullo, J., Guo, Z. T., Kiefer, T., and Liu, Z. Y.: The global monsoon across timescales: coherent variability of regional monsoons, Clim. Past, 10, 2007-2052, https://doi.org/10.5194/cp-10-2007-2014, 2014.

Wassenburg, J. A., Immenhauser, A., Richter, D. K., Jochum, K. P., Fietzke, J., Deininger, M., Goos, M., Scholz, D., and Sabaoui, A.: Climate and cave control on Pleistocene/Holocene calcite-toaragonite transitions in speleothems in Morocco: elemental and isotopic evidence, Geochim. Cosmochim. Ac., 92, 23-47, 2012.

Wassenburg, J. A., Dietrich, S., Fietzke, J., Fohlmeister, J., Jochum, K. P., Scholz, D., Richter, D. K., Sabaoui, A., Spötl, C., Lohmann, G., Andrae, M. O., and Immenhauser, A.: Reorganization of the North Atlantic Oscillation during early Holocene deglaciation, Nat. Geosci., 9, 602-605, 2016.

Webb, M., Dredge, J., Barker, P. A., Müller, W., Jex, C., Desmarchelier, J., Hellstrom, J., and Wynn, P. M.: Quaternary climatic instability in south-east Australia from a multi-proxy speleothem record, J. Quaternary Sci., 29, 589-596, 2014.

Wedepohl, K. H.: The composition of the continental crust, Geochim. Cosmochim. Ac., 59, 1217-1239, 1995.

Wurth, G., Niggemann, S., Richter, D. K., and Mangini, A.: The Younger Dryas and Holocene climate record of a stalagmite from Hölloch Cave (Bavarian Alps, Germany), J. Quaternary Sci., 19, 291-298, 2004.

ZAMG: Das Klima von Tirol-Südtirol-Belluno, Zentralanstalt für Meteorologie und Geodynamik, Vienna, 2015. 